\title{
How to challenge a culturalization of human existence? Promoting interculturalism and ethical thinking in education
}

Frédérique Brossard Børhaug

NLA Høgskolen

FrederiqueBrossard.Borhaug@NLA.no

\author{
Keywords \\ culturalization \\ interculturalism \\ monocultural and intercultural education \\ Levinas's ethics
}

Frédérique Brossard Børhaug, How to challenge a culturalization of human existence? Promoting interculturalism and ethical thinking in education 


\begin{abstract}
What if culture appears to be a universal solution - and problem - to all human encounters in the multicultural school? When teachers explain the problems encountered by minority pupils simply by reference to their cultural (religious) backgrounds, one faces the danger of culturalization where the other's difference is explained only by his/her ethnicity. Culturalization is highly problematic because it emphasizes stereotyped inter-group differences and by doing so erases intra-group and inter-individual differences. The article argues that culture is fundamental in human existence, but it should not be an ambiguous dimension if the school seeks to help the learner get a stronger capacity of voice and aspiration. In order to challenge culturalization of human existence, it is crucial for education to promote the paradigm of interculturalism. Such a paradigm requires educators to acknowledge multiple forms of identity belongings for the individual and to resist the interpretation of culture as common sense. Education becomes intercultural and provides liberating categorizations for the individual when it acknowledges the true value of chosen cultural affiliations and individual aspirations. Nonetheless, promoting interculturalism might not be sufficient. Facing the potential danger of culturalization, we also need to foster ethics in education, in order to deconstruct the categories of cultural identity and belonging. Drawing on the philosophy of Emmanuel Levinas (1905-1995) the article argues that loving the other implies the act of loving the other person as a brother and as a stranger. Responsibility understood as an ethical responsibility opens up the community's traditional structures and promotes a politics of ethical difference. Justice, thus, is not only about how well rights and duties are enforced, but also a matter of the other's right to be other. Difference as a category is in other words not cultural but refers to the fundamental uniqueness of each subject, defined as both a concrete and irreplaceable human being. Although Levinasian ethics is demanding and does not provide any concrete guidance to educators, it adds a necessary dimension of definition and justification to our responsibility towards the other beyond any categorization. Consequently, a pedagogy of ethical disruption and the event of ethical subjectivity is made possible through the exploration of intercultural education.
\end{abstract}




\section{Introduction}

The article is a theoretical contribution about intercultural education. It raises the question of culturalizing human existence and argues that culturalization is highly questionable because it implies negative categorizations of the other and a simplistic view of culture understood as common sense. A main argument in the article is that culturalization reduces individuals' abilities to choose multiple forms of belonging and supports a culturalized and deficit-based mode of thinking about the minority pupil's school performance. Trying to exemplify the problematic notion of culturalization in education, concrete episodes drawn from the French school context are provided. These demonstrate that teachers justified the educational problems of some minority pupils and families by stressing their deficient cultural background and life experiences. In that way, culture becomes culturalization, excluding the other from the community based on the dominant group's norms and structures.

How then can intercultural education challenge the culturalization of human existence? The purpose of this article is twofold. Firstly, it is important to develop nuanced categories of cultural belongings; the article argues that the paradigm of interculturalism can promote such development because it critically questions culturalization that is based on stereotyped inter-groups differences. Indeed, interculturalism seeks to promote a renewed understanding of the other paying attention to multiple identity categorizations where intergroup differences, but more importantly intra-group and inter-individual differences, are at stake. Secondly, it is necessary to develop another language in intercultural education that is not solely based on the concepts of culture and identity. Based on Emmanuel Levinas's ethics, the article seeks to promote a mode of ethical thinking that can contribute to challenging culturalization; in this mode of ethnical thinking difference is no longer understood as a cultural matter but rather as a responsibility and irreplaceability towards the other. Even though Lévinasian ethics is demanding and leaves educators without concrete guidance, it may help to promote further critical thinking about human existence and the use of culture in intercultural education.

\section{Facing the danger of culturalizing human existence in education}

Culture is an ambiguous notion in education. No human being lives in a vacuum; quite to the contrary, every human being belongs to a particular cultural context and uses subcultures to exist in diverse ways. Thus, we understand cultural ways of life as a decisive factor for the human condition. However, what importance should we ascribe to the category of culture within the field of education? What should we do when culture becomes a pervasive issue at a school, such that it determines all kinds of issues, often at the expense of minority pupils? This article argues that without a thoughtful view of the notion of culture, educators may give in to a culturalization of human existence and adopt a monocultural view of education. Yet, it is also important to point out that culturalization is a complex notion that can be understood in contradictory ways. For instance, Parsons (2000, 2003) supports the idea of culturalizing instruction by multiculturalizing learning environments, and argues that teaching is a value-laden activity that is often based on the dominant group's cultural ethos (here the White Americans of European descent). She calls for the recognition of African Americans' cultural values and provides several examples of culturalized science instruction based on a Black cultural ethos (2003, pp. 24-25). While Parsons' endeavor is worth noting, culturalization raises questions about connotative representations of the other, especially the non-Western minorities. For instance Annfelt and Gullikstad (2013) show that the current Norwegian gender discourse reinforces 
stereotypes about non-Western women by supporting the view that their home cultures are a major factor in their low rates of participation in the workforce (p. 315); by failing to portray them as active and resourceful; and by failing to highlight asymmetrical power and discriminatory practices (2013, p. 319). Such a process is defined as a culturalization of gender mainstreaming, where culture is used as an all-encompassing frame of interpretation (2013, p. 323). Attempting to describe what constitutes culturalization in education, let's start with some concrete examples from a French school context.

I have witnessed several situations where teachers explicitly consider minority pupils in general as "problematic pupils". Some teachers told me that if minority pupils get bad school results and have disruptive behaviors in class, it is because they and their parents don't speak French, they don't know French culture and they don't know or don't want to accept French values. Some of them even concluded that they only know one thing: Islam! I think that such a view is highly problematic because the minority pupil's school failure becomes thereby culturalized. In other words, some minority pupils' under-performance is explained in terms of a deficient social and cultural home environment supposedly unwilling or unable to support the pupil's schooling. The under-performance is thus not linked to the reproduction of ethno-cultural and social privileges given to dominant groups but by a deficit-based thinking where the individual agency of minority pupils is hampered by a problematized and culturalized family education (Clycq et al., 2014). Based on reductionist and misleading interpretations of the other, some teachers fail to reason critically about the plurality of human existence, or to acknowledge the pupil's cultural identity and mother tongue. These failures help to strengthen the grip of the monocultural discourse, already deep-rooted in education.

Monocultural education can be earmarked by various overlapping factors. For example, cultural groups are deemed static and homogeneous (Lahdenperä, 2000) and there is a hierarchic representation of cultures where non-Western cultures are regarded as more primitive and less creative (Ytrehus, 2001). The above examples from the French school context are clear evidence of these views. The school implements assimilative and compensatory strategies attempting to mask differences and reduce the ethnic, cultural and linguistic complexity (Horst \& Gitz-Johansen, 2010; Norberg, 2000). A problem-centered approach to diversity based on a binary understanding of social relations (Us/Them) is prevalent in school practice, and a monolingual education in favor of the majority language is implemented (Timm, 2009). Monocultural educational policies also maintain a Eurocentric norm traditionally based on the Christian and/or secular humanist patterns, and selfsufficient, heterosexual, white majority male without physical or mental disorders (Horst, 2010). If and when minority students' learning processes are taken into consideration, they are addressed most of the time in terms of cultural and linguistic deprivation and lack of resources that needs to be redressed (Hauge, 2014).

However, I believe that there is another challenge with the notion of culture becoming ambiguous and I argue that the challenge is when culture is used as common sense. Based on Biesta's understanding of competence as common sense (2014), I argue that culture as common sense can eventually underlie a deficit-based and culturalized thinking about minority pupils' schooling.

Biesta states that common sense features a particular view where specific ideas are presented as general and neutral, and as relatively uncontested (pp. 123-124). To exemplify the problem of common sense, he analyses the rise of the concept of competence in education and teacher education. The main argument is that all teachers should be competent. Indeed, it seems reasonable that we need very competent teachers in a competitive world, but the discourse on competence tends to cover all possible aspects of 
teaching and leads to long checklists of everything teachers should be competent about. Acknowledging the vital role of the teacher only through competence achievement is a limited view because it tends to minimize the development of professional judgment. Such a capacity is crucial for the teacher when he/she encounters new and unpredictable situations in the classroom (pp. 119-124). More specifically, Biesta states that

What is worrying ... is perhaps not so much the notion of competence itself - it is a notion with a certain appeal and some potential - but first and foremost the fact that the idea of competence is beginning to monopolize the discourse about teaching and teacher education. It is, therefore, first of all the convergence towards one particular way of thinking and talking about teaching and teacher education that we should be worried about. After all, if there is no alternative discourse, if a particular idea is simply seen as common sense, then there is a risk that it stops people from thinking at all. (2014, pp. 122-123)

Thus, one should consider that a hegemonic discourse does not change everything but brings people to amend their ways of thinking which leads to less ability to think differently and respond creatively to changes in the social and biological environment. In hegemonic situations common sense will promote a particular view about education and this view will be repeated and multiplied (p. 123).

Following Biesta's understanding of competence as common sense in the current educational discourse, I ask whether we face a similar issue regarding the concept of culture in multicultural schools: concentrating educational thinking and practices on the notion of culture but without a substantial and critical analysis of its limits. More specifically, by being a rich and emancipating category, a dominant view on culture is soon set up, making each one of us a representative of one culture, one language, and one religion. Other dimensions of human existence that are making possible the diversity and uniqueness of each human being become negligible and the individual is eventually culturalized (Berg \& Fladstad, 2012). Abdallah-Pretceille shares the same preoccupation, arguing that

If educational effectiveness becomes defined in terms of focusing on learning profiles according to cultural membership, there is a risk that education and training will become culturalized by highlighting inter-groups differences to the detriment of intragroup and inter-individual differences. Between the 'cultural zero', meaning the ignorance or negation of the cultural dimension of education and the 'cultural all', meaning an overemphasis on culture as a determining factor of behavior and learning, the margin of manoeuvring is narrow. The fairly recent emphasis pushes us in the direction of 'dictatorship' of the cultural by reducing the individual to his/her cultural membership. (2006, p. 476)

Consequently, we need to highlight the ambiguity of the notion of culture and resist a process where culture appears to be the sole factor used to explain all conflictual relations and learning difficulties in the multicultural school. In many ways, we need to establish a new paradigm in education. 


\section{Interculturalism as a new paradigm}

Abdallah-Pretceille (2006) promotes such an alternative paradigm within education. She defines culture as a category that promotes individuality, complexity, and unpredictability in rich and heterogeneous cultural contexts and seeks to enhance the specificity of actions and situations. She advocates a pragmatic and hermeneutical approach where the subject acts and interacts with other subjects, forming his or her identity in a continuous creation process. Thus, in contrast to culturalist definitions that attribute fixed categorizations and artefacts to cultural groups reinforcing stereotypes, exoticism and cultural dead-ends, interculturalism promotes a permanent questioning of human relations. Rich hypotheses and a plurality of interpretations are formulated in a context where educators acknowledge the otherness of the subjects through their subjective personal experiences (2006, pp. 476481). But interculturalism is not limited to the act of recognizing the other's individuality and cultural diversity; it also promotes intercultural education. More generally, we could say that intercultural education seeks to reduce social inequality in multicultural societies (Gundara \& Portera, 2008; Portera \& Grant, 2011; Portera, 2008), paying careful attention to the vivid diversity of national contexts and to various educational fields (Bleszynska, 2008).

Nonetheless, promoting interculturalism in education is not an easy task because it raises difficult questions about the human condition and opposes the hegemony of monocultural school discourses and practices that exclude diverse minority groups (Brossard Børhaug, 2013; Clycq et al., 2014; Horst \& Gitz-Johansen, 2010; Pihl, 2010; Øzerk, 1993). It thus requires intent resistance, creativity and dialogue from intercultural educators in order to establish a paradigm that currently lacks conceptual clarity (Gundara \& Portera, 2008; Portera, 2008).

As stated previously, culturalization of human existence implies enclosing human beings in stereotyped attributes. Therefore, it is important to promote freedom for the individual and help him/her make valuable choices. Amartya Sen argues that "we are diversely different" (2007: xvi), but states that the individual's freedom is often limited because of the illusion of a singular choiceless identity (pp. 5-8). In other words, culture does matter, but the real question is how to avoid too narrow a view of cultural attributes that confine human beings to particular identities, making them "imaginary slaves of an illusory force" (p. 103). To resist such an illusion of culturalized destiny, we need non-sectarian education advocating the plurality of human nature and the right to choose multiple belongings ( $p p .119,182$ ). In other words, "every individual has the potential to express him/herself and act not only depending on their codes of membership, but also on freely chosen codes of references" (Abdallah-Pretceille, 2006, p. 478).

\section{Promoting freedom, aspirations and responsibility in education}

Promoting the individual's substantive freedoms implies that the school is able to help the learner achieve a stronger capacity of voice and aspiration. However, acknowledging the subject's uniqueness and freedom cannot be done without considering the multiplicity of languages, religions, institutional norms, political practices and ethnic belongings as irreducible social goods. According to Charles Taylor, they are objects of value that cannot be reduced to individual acts; they exist beyond individual lives but are endorsed by individuals (Deneulin, 2006, p. 55; 2008, p. 109-110). A language exists beyond individuals, but will not survive without being used. Consequently, intercultural education will strive to preserve the plurality of languages globally and reinforce the individual capacity of voice and aspiration locally (Skuttnabb-Kangas et al., 2009). This capacity can 
be considered as a navigational capacity where the individual learns to use his or her own knowledge, experience and opportunities in a more effective way (Appadurai, 2004; Brossard Børhaug 2013). The capacity of voice and aspiration should be developed at school for every pupil through continuous practice, repetition, and exploration. Melanie Walker argues that

When schooling fosters voice, here understood as the capacity to debate, contest, inquire, and participate critically, it simultaneously nurtures aspiration. Where children might be denied a capability of voice at home or in society . . . there is then a particular ethical responsibility for the school to challenge exclusion, not to perpetuate it. (2007, p. 184)

If they do not grow this capacity, learners may develop scepticism, violence or uncritical compliance with the curriculum and the social order, and their aspirations eventually become more rigid and binary, presenting the world in black and white without the plurality of nuances and openness. This argument is especially important when culturalized and deficit-based thinking prevails in school discourses and practices. A significant example is the current Norwegian legislation regarding mother tongue teaching, considered as a major setback compared to the 1980's (Øzerk, 2010). Too strong a focus on the majority culture and language - seen as the "supreme category" - in the definition of the educational mission in Norwegian schools leads to diminished freedom of choice and learning outcomes for many minority pupils (Hauge 2014). Thus trying to explain the minority pupils' underperformance, some teachers might put the blame on their upbringing, their background, their family or the children themselves. Such an explanation is deceitful. In order to resist culturalized and deficit-based thinking, one must assert that additive bilingual teaching, combining mother tongue with second language teaching, can reinforce the capacity of aspiration in several languages, an ability that can provide a more constructive motivation for each person to engage in and contribute to the democratic life of a pluralistic society. In other words, it may give individuals better opportunities to formulate and make valuable choices in order to build a more sustainable present and future for themselves and others.

Therefore, the pivotal notion of culture needs to be transformed into a reflective category where it is important to recall the potential danger of any categorization. In many ways, culture is often seen in the public realm as a universal solution - and problem - to all human encounters. Philippe Meirieu warns against what he calls "lethal categorizations" (2008). We need categories based on identified needs that can contribute to greater justice, but these categories must not be immutable and closed dimensions. Otherwise, they will act as ghettos that block individual and collective life paths. In other words, any category should liberate the individual and help him/her be a better person (p. 111). Consequently, we need to set up an education system that resists common sense thinking and oppressive social conventions, where the pedagogue teaches the new generation the possibility to say no, calling systematically into question what appears to be traditional and "normal". Education should prepare the individual to make reasoned life choices based on critical thinking, but not without taking responsibility for his or her own actions (2013). Meirieu clearly advocates a model of education that promotes the emergence of freedom, where the subject is given opportunities to express and act, calling into question categories of all kinds ". . . exploring missed opportunities for identification of possible futures" (ibid, p. 145) ${ }^{1}$. Consequently, thinking alternatively and creatively can unlock destiny, but freedom and critical thinking cannot be elaborated without learning to take responsibility for one's own

1 "... explorer des occasions ratées pour identifier des futurs possibles" (Meirieu, 2013, p. 145). 
actions (2013, pp. 129-130, pp. 144-145). This model implies that educators have an ethical duty to resist an oppressive society and strive to construct a better future (2008, 2013), an argument that is also important for the further development of intercultural education.

In short, it is crucial for education to promote the paradigm of interculturalism. Such a paradigm implies that the school should acknowledge multiple forms of identity belongings and resist culturalized and simplistic interpretations. Education thereby becomes intercultural and provides categorizations that liberate the individual and accept the true value of chosen cultural affiliations combined with individual aspirations and responsibility. Nonetheless, this alone might not be sufficient. Facing the potential danger of culturalization, we also need to foster ethical thinking in education that can deconstruct the categories of cultural identity and belonging. This is my next claim.

\section{Levinas's ethics: A possible contribution with intercultural education?}

Meirieu's argument about teaching responsibility for one's own actions is a notion that I wish to explore further. Previously, I argued that thinking critically and creatively about the category of culture is important in any intercultural teaching resisting widespread monocultural and deficit-based thinking and practice. Nonetheless, I believe that this is not enough. In order to preserve and develop good and long-lasting structures for living together, a wider ethical issue is at stake, and we need to acknowledge the role of ethics in intercultural education. After all, culturalization and discrimination cannot be considered solely as a societal problem but as an ethical one too, because they jeopardize society's moral norms and laws, as well as good human relations. Thus, it is necessary to support the intercultural educational project by also developing an ethical thinking on the essence of man and the finality of his socialization. In order to discuss these difficult questions, I will draw on the ethics of Emmanuel Levinas (1905-1995), a French-Lithuanian philosopher.

Emmanuel Levinas experienced lethal categorizations in person. He was a Jewish prisoner in a labor camp in Germany during World War II and describes his experience of being defined as non-human.

There were seventy of us in a forestry commando unit for Jewish prisoners of war in Nazi Germany. [...]The French uniform still protected us from Hitlerian violence. But the other men, called free, who had dealings with us or gave us work or orders or even a smile - and the children and women who passed by and sometimes raised their eyes - stripped us of our human skin. We were subhuman, a gang of apes. A small inner murmur, the strength and wretchedness of persecuted people, reminded us of our essence as thinking creatures, but we were no longer part of the world. Our comings and goings, our sorrow and laughter, illnesses and distractions, the work of our hands and the anguish of our eyes, the letters we received from France and those accepted for our families - all that passed in parenthesis. We were beings entrapped in their species; despite all their vocabulary, beings without language. [...]It shuts people away in a class, deprives them of expression and condemns them to being 'signifiers without a signified' and from there to violence and fighting. How can we deliver a message about our humanity which, from behind the bars of quotation marks, will come across as anything other than monkey talk? (1990, pp. 152-153)

Indeed, Emmanuel Levinas makes the same point as Meirieu, Sen and Abdallah-Pretceille, warning against totalizing representations erasing language and the other's uniqueness. His call for caution has not lost its normative strength after the tragedy of the 22 July 2011 in 
Norway, the terror attacks in Paris in 2015 and everyday antisemitism, populism and islamophobia in school and society (Eidsvåg, 2011). Nevertheless, his philosophy brings a new element countering the discourse on who is the stranger, helping educators to deconstruct the category of culture in education.

\section{The uniqueness of the subject, meeting the other's otherness}

The other's strangeness is usually defined as having another ethnic background. However, in Levinas's ethics the other's otherness becomes an ethical concern and an inescapable dimension of human existence. More specifically, Levinas argues that the essence of man is not a matter of the identity, physical and psychological attributes or status one may have, or current roles one may play in society. Meeting the other is meeting another person - a human being essentially different from me - a stranger to me. In an interview with François Poirié, he says:

But beyond any attribute, you are someone other than me, otherwise other, absolute other. And this is this other otherness that the one that holds the attributes that constitutes your otherness; it is logically unjustifiable, logically indistinguishable. [...] You are you and I am me: it is not simply the fact that we differ in our bodies or the color of our hair or the place we occupy in the space (Poirié, 1996, p. 109, my translation $)^{2}$

So, the other's uniqueness is not a dimension in human life that we can conceptualize through knowledge and definitions. However, we daily try to do so, neglecting the fundamental human difference by putting everyone - oneself included - into some better or worse categories. In Levinas's words, we try to assimilate the other. Yet, such attempts are unethical and impossible; the other's uniqueness cannot be generalized. For Levinas, we are all strangers in the act of responsibility (Brossard Børhaug, 2008).

\section{The event of subjectivity; a responsibility towards the other}

However, how can we define responsibility towards the other, the stranger? Zygmunt Bauman shows how ethical responsibility is defined in terms of a dyadic relation between the singular I and the other, where the self acknowledges the face of the other as his sole and total responsibility (1998, p. 85). The face of the other is without any concrete power but still commands the I: "you shall not kill". Thus, the ethical responsibility is not primarily defined in terms of duties and rights but as an asymmetrical relation where the singular I takes responsibility for the other, and cares without expecting reciprocity. The face in all its fragility commands the self. It is an authority but without any power, a prayer of care without any enforcement power. Levinas says:

The neighbor concerns me before all assumption, all commitment consented or refused .... . I am as it were ordered from the outside (1998: 98-99). Places thus get changed where the other acquires that priority which traditionally has been assigned to the autonomous self (Levinas cited in Bauman, 1998, p. 85).

\footnotetext{
2 Mais avant tout attribut, vous êtes un autre que moi, autre autrement, autre absolument! Et c'est cette altérité autre que celle qui tient aux attributs, qui est votre altérité; elle est logiquement non justifiable, logiquement indiscernable. [...] Vous êtes vous et moi, je suis moi: cela ne se réduit pas au fait que nous différons par notre corps ou par la couleur de nos cheveux ou par la place que nous occupons dans I'espace.
}

Frédérique Brossard Børhaug, How to challenge a culturalization of human existence? Promoting interculturalism and ethical thinking in education 
In this way, the face of the other is resistant to knowledge and cannot be characterized. The face is without context, without horizon, without concepts and surroundings (Aarnes, 1998, p. 161). And more important than the Greek ideal of knowledge, is the Biblical act of loving the other, says Levinas to Poirié (1996, p. 134). However, ethical respect and responsibility for the other implies, as Sharon Todd argues, "receiving her in all her alterity [...] [that is] not treating the other as another rational subject like myself, but about responding to her specificity in a way that secures her right to be other" (2009, p. 111).

Thus, Levinas's philosophy reminds us that each human being is fundamentally unique, and owes a responsibility towards the other, considered as a brother while remaining a stranger. Biesta argues that Levinas "has articulated a completely different 'avenue' towards the question of human subjectivity" (2014, p. 19), considering responsibility as irreplaceability. He challenges the idea of the self as the center of meaning and initiative, where the self is concerned firstly about its own well-being and if it decides to do so, cares for the other's welfare in the second place (2014). Subjectivity for Levinas means first of all to be engaged in an ethical relationship with the other that has priority over principles and the ego itself. Responsibility becomes in other words irreplaceability, where the self cannot be replaced by someone else. In the act of responsibility I become unique and irreplaceable; only myself becomes responsible for the other's life and such responsibility is not transferable (p. 21). This ethical responsibility is not an attribute of any kind, it is simply there and given. Subjectivity thus has to do with how I take responsibility for my responsibility (Biesta $2015 a / 2015 b)$. Responsibility is not something that I can humanely refuse even if in everyday life we often chose to do so, we forget the other ${ }^{3}$, we do not encounter them as "subjects in their own rights" but as "objects of our actions and intentions" (Biesta, 2015b, p. 6).

In many ways, the notion of ethical responsibility can be seen as a critical response to the institutionalized responsibility of modern society. Levinas is not opposed to particular institutions and laws. On the contrary, he believes that we need these because they safeguard us against conflicts and war. But they do not offer a deeper peace. According to Levinas, institutionalized responsibility offers

A bad peace. Better indeed than a good war! But yet an abstract peace, seeking stability in the powers of the state, in politics, which ensure obedience to the law by force (Levinas, 1993, p. 122).

Responsibility under the state system is defined in terms of rights, duties and belongings, but if you don't belong to the "right" categories, you are not protected. Levinas's philosophy questions a traditional understanding of the public sphere. More specifically, based on predefined notions, the public sphere categorizes each person as belonging - or not - to the community. Thereby, the public sphere appears to be open/closed to many persons. By contrast, Levinas makes the case for proximity, which he understands as "the unique quality of the ethical relation" (Bauman, 1998, p. 87), not as spatial proximity. The community is in other words considered as having a dual structure: a social system based on reciprocal and equal rights, and the asymmetrical responsibility of the self towards the other (Brossard Børhaug, 2008, p. 62).

Therefore, ethical responsibility can reveal how unfair the social order can be. Very restrictive European immigration policies rejecting the duty of hospitality towards migrants from the South crossing the Mediterranean Sea by boat, the rise of populist political parties, diverse forms of racist thinking and discriminatory practices, all show the current propensity towards self-centeredness and indifference towards the other's suffering, a focus that puts

3 In Norwegian "nesteglemselen" (Aarnes, 1998, p. 162).

Frédérique Brossard Børhaug, How to challenge a culturalization of human existence? Promoting interculturalism and ethical thinking in education

Ambivalence, Vol. 3, No.1/2016 
the interests of the self and the in-group above all others' (Taguieff, 2012). Nussbaum calls this attitude "an excessive self-concern that damages love" (2012, p. 57). The ideological worship of the "I" and "we" based on categories such as culture, ethnicity, race, class, gender etc. seeks therefore to promote "our" group as the chosen and supreme group. In other words, as explained by Levinas, justice defined as equal rights does not offer an ultimate guarantee for positive peace; in current rational and legal societies, many members are marginalized, in spite of having equal rights under law.

\section{Subjectivity as an ethical event in the exploration of intercultural education}

Consequently, Levinas's ethics is strongly critical of any attempt to know the other as oneself. He sees the self as inextricably bound to the other in the act of responsibility, while the other nonetheless remains a stranger (Poirié, 1996). I suggest that Levinas's ethics can help to weaken the strong cultural discourse in schools, by promoting a view that people are bound not primarily by ethnic, but by ethical considerations. The ethical responsibility is the matter of the I (Lévinas, 1993), and I suggest that responsibility without regard to ethnic background is an important issue to discuss in intercultural education because it may promote a deeper meaning of plurality in human existence. Following Biesta's distinction between grown-up and infantile ways of acting and responding to the other (2015a/2015b), I propose to consider responsibility not in terms of formal rights and duties, but primarily as a fundamental act of love that makes dialog and adult behavior existential qualities (2015b, p. 9). Whereas infantile ways are egocentric, taking "the self as a point of reference" (p. 2), a logic that is "entirely generated from the desires of the ego" (p. 10), grown-up actions allow for interruptions and suspensions, "asking the question what we desire is desirable for our own lives and the lives we live with others" (p. 10). Because the other sends me a call that only I can respond to, it implies "an interruption of my 'immanence,' the being for and with myself" (p. 11, italics in original). Following Biesta's argument, I suggest that culturalizing human existence means that the minority pupil becomes an object in the educator's judgment, preventing the child from emerging as a subject reflecting on "one's desires and their possible desirability" (p. 12). It deprives the subject from being resourceful and active, as mentioned earlier by Annfelt and Gullikstad (2013). Without such an educational endeavor, the child might address the world in a destructive way, trying to shape it excessively following his/her infantile desires or withdrawing from it, abandoning aspirations and hopes. Being told that "their background and existence do not fit the standards", one may wonder how the child will meet the world in a meaningful and positive way, keeping him/herself away from world destruction and self-destruction. Biesta states that

... perhaps the latter is the most crucial one, as it is only if the child has the will to be in the world that the (trans)formation of this will power so that it does not result in the destruction of what and who is other, becomes an option to work on. (p. 13)

Educators are responsible for the child, but they are also responsible for not developing infantile behaviors themselves leading to deficit-based and problematic thinking about the pupil's existence.

Therefore, we might say that Levinas's philosophy questions legal justice and its practices, and reintroduces ethical difference within the political community. The community remains a place for unity, being at the same time open, respectful of difference and resistant to closure within "a politics of ethical difference" (Critchley, 1999, pp. 219-239; Lévinas, 1982, pp. 74-75). I think that Levinas's opposing voice is a necessary ethical "backlight" within an 
educational debate traditionally concerned with the emergence of the citizen "in the making", its autonomy, rights, rationality and cultural identity. Like the sunlight on the window revealing its dirt, Levinasian thinking helps us revisit our categories, deconstruct simplistic interpretations in educational issues and culturalization trends that are ultimately tearing people apart. Human difference has an ethical dimension and intercultural education bears an ethical duty to promote responsibility towards the other.

Let me finish the article by returning to Levinas's story about the work camp during World War II. He says

And then, about halfway through our long captivity, for a few short weeks, before the sentinels chased him away, a wandering dog entered our lives. One day he came to meet this rabble as we returned under guard from work. He survived in some wild patch in the region of the camp. But we called him Bobby, an exotic name, as one does with a cherished dog. He would appear at morning assembly and was waiting for us as we returned, jumping up and down and barking in delight. For him, there was no doubt that we were men (1990, pp. 152-153).

This is a short but profound story revealing that only one dog was affirming the dignity of the person, while other human beings were denying it. The story presents a clear paradox for our educational project, which is to prepare ourselves and the new generation to acknowledge that "loving someone simply means acknowledging his/her being as much as yours" (Weil cited in Collectif, 2007, p. 61) .

However, Levinas does not address how one should take responsibility for the other, the brother and the stranger. His ethics raise difficult questions. Are we capable of being responsible for and loving the other, as Levinas recommends? Or is it an ethics for 'angels'? Levinasian philosophy is not comforting; it is rather, as Todd says, "a relentless examination of the ways in which violence plagues our lives and our capacities for responding in the face of them" (2009, p. 20). No program of moral education is prescribed; because subjectivity is an ethical event (Biesta, 2014, p. 22), a possibility of ethical disruption and a provisional hospitality (Todd, 2009, p. 112), there is no guarantee that it will happen. Levinas leaves our pedagogy empty-handed (Biesta, 2014, p. 22-23) but not without a worthy reflection on human existence.

In conclusion, I suggest that it is necessary to reflect on the limitations of the role of culture in education. Similarly, interculturalism and Levinasian ethics should be included in educational discourses and practices where culture seems to be an omnipotent category. Of course, we need culture for our co-existence. Our responsible actions are ruled by specific laws, norms and traditions, which are part of the ethical base of our living together. Thus, in his/her existential endeavor, the subject is an historical being interpreting and acting, confirming that interculturalism is hermeneutic (Abdallah-Pretceille, 2006). Still, if we follow Levinas, there is no final certainty for our common destiny. In our current democratic quest, difference must be understood not only as multiple identity belongings, but as the fundamental uniqueness of every human being, and as a responsibility that is not chosen and not fully understandable. This asymmetrical responsibility is fundamental if we seek to enjoy meaningful and responsible lives together. It implies an education that makes us open to what is calling us - the event of subjectivity. It also implies an exploration of intercultural teaching and practices.

4 « Aimer un être c'est tout simplement reconnaître qu'il existe autant que vous » (Weil cited in Collectif, 2007, p. 61).

Frédérique Brossard Børhaug, How to challenge a culturalization of human existence? Promoting interculturalism and ethical thinking in education 


\section{References}

Abdallah-Pretceille, M. (2006). Interculturalism as a paradigm for thinking about diversity. Intercultural Education, 17, 5, 475-483. http://dx.doi.org/10.1080/14675980601065764

Annfelt, T. \& Gullikstad, B. (2013). Kjønnslikestilling i inkluderingens tjeneste? Tidsskrift for kjønnsforskning, 3-4(37), 309-328.

Appadurai, A. (2004). The capacity to aspire: Culture and the terms of recognition. In V. Rao \& M. Walton (Eds.), Culture and Public Action: A Cross Disciplinary Dialog in Development Policy (pp. 59-84). Palo Alto, California: Standford University Press.

Bauman, Z. (1998). Postmodern ethics (first published in 1993). Oxford: Blackwell Publishers.

Berg, B. \& Fladstad, T. (2012). Bildene i hodet. Forestillinger om funksjonshemming. I B. Berg (Eds.), Innvandring og funksjonshemming (pp. 74-103). Oslo: Universitetsforlaget.

Biesta, J.J. G. (2014). The beautiful risk of education (first published in 2013). Boulder: Paradigm Publishers.

Biesta, J.J.G. (2015a). Hva en pedagogisk oppgave? Om å gjøre voksen eksistens mulig. In P. O. Brunstad, S. M. Reindal\& H. Sæverot (Eds), Eksistens og pedagogikk: En samtale om pedagogikkens oppgave (pp. 194-209). Oslo: Universitetsforlaget.

Biesta, J.J.G. (2015b). What is an educational task? On making grown-up existence possible. Unpublished in English.

Bleszynska, K. M. (2008). Constructing intercultural education. Intercultural Education, 19, 6, 537-545. http://dx.doi.org/10.1080/14675980802568335

Brossard Børhaug, F. (2008). Skolen mot rasisme. En sammenligning av antirasistiske verdier i fransk og norsk læreplandiskurs (Doktoravhandling). Det utdanningsvitenskapelige fakultet, Oslo.

Brossard Børhaug, F. (2013). Conflicting anti-racist values in Norwegian and French civic education: To what extent can the curriculum discourses empower minority youth? I G. Gudmundsson, D. Jr. Beach, \& V. Vestel (Red.), Youth and Marginalisation: Young People from Immigrant Families in Scandinavia (s. 105-131). London: Tufnell Press.

Clycq, N., Nouwen, W. M. A. \& Vandenbroucke, A. (2014). Meritocracy, deficit thinking and the invisibility of the system: Discourses on educational success and failure. British Educational Research Journal, 40(5) 796-819. http://dx.doi.org/10.1002/berj.3109

Collectif (2007). Les mots pour combattre le racisme. Paris: Éditions Milan, Carré philo. Critchley, S. (1999). The ethics of deconstruction: Derrida and Levinas (2nd ed.). Edinburgh: Edinburgh University Press.

Deneulin, S. (2006). The capability approach and the praxis of development. New York, NY: Palgrave MacMillan. http://dx.doi.org/10.1057/9780230627253

Deneulin, S. (2008). Beyond individual freedom and agency: Structures of living together in Sen's capability approach to development. In: S. Alkire, F. Comim and M. Qizilbash (Eds.), The capability approach: Concepts, measures and application (pp. 104-123). Cambridge University Press. http://dx.doi.org/10.1017/СBO9780511492587.005 
Eidsvåg, I. (2011). Det kan skje igjen. Rapport fra Kunnskapsdepartementets arbeidsgruppe om antisemittisme og rasisme i skolen. Oslo: Kunnskapsdepartement. Retrieved from http://www.regjeringen.no/nb/dep/kd/dok/rapporter planer/rapporter/2011...

Gundara, J. S. \& Portera, A. (2008). Theoretical reflections on intercultural education. Intercultural Education, 19, 6, 463-468. http://dx.doi.org/10.1080/14675980802568244

Hauge, A.-M. (2014). Den felleskulturelle skolen (3rd ed.). Oslo: Universitetsforlaget. Horst, C. (2010). Læringsteori mellem identitetspolitik og ligestillingskampe:

Positioneringer af lighed i interkulturel pædagogikk, Unpublished.

Horst, C. and Gitz-Johansen, T. (2010). Education of ethnic minority children in Denmark: monocultural hegemony and counter positions. Intercultural Education, 21, 2, 137-151. http://dx.doi.org/10.1080/14675981003696271

Lahdenperä, P. (2000). From monocultural to intercultural educational research. Intercultural Education, 11, 2, 201-207. http://dx.doi.org/10.1080/713665246

Lévinas, E. (1982). Éthique et infini: Dialogue avec Philippe Nemo. Paris: Arthème Fayard et Radio-France.

Lévinas, E. (1990). Difficult Freedom: Essays on Judaism. Baltimore: The Johns Hopkins University Press.

Lévinas, E. (1993). Outside the subject (first published in French in 1987). London: The Athlone Press.

Meirieu, P. (2008). le choix d'éduquer : Ethique et pédagogie (2nd ed.). Issy-lesMoulineaux: ESF, Pédagogies.

Meirieu, P. (2013). Pédagogie: Des lieux communs aux concepts clés. Issy-lesMoulineaux: ESF, Pédagogies.

Norberg, K. (2000). Intercultural education and teacher education in Sweden. Teaching and teacher education, 16, 511-519.

http://dx.doi.org/10.1016/S0742-051X(00)00008-1

Nussbaum, M. C. (2012). The new religious intolerance: Overcoming the politics of fear in an anxious age. Cambridge: Harvard University Press.

http://dx.doi.org/10.4159/harvard.9780674065918

Parsons, Carlton E. (2000). Culturalizing science instruction : What is it, what does it look like and why do we need it ? Journal of science teacher education, 11(3), 207219. http://dx.doi.org/10.1023/A:1009448523133

Parsons, Carlton E. (2003). Culturalizing instruction : Creating a more inclusive context for learning for African American students. The High School Journal, 86(4), 23-30. http://dx.doi.org/10.1353/hsj.2003.0009

Pihl, J. (2010). Nasjonale minoriteter og det flerkulturelle Norge - utsyn. In A. Bonnevie Lund \& B. Bolme Moen (Eds.), Nasjonale minoriteter i det flerkulturelle Norge (pp. 251-262). Trondheim: Tapir akademisk forlag.

Poirié, F. (1996). Emmanuel Lévinas: Essais et entretiens (2nd ed.). Paris: Babel, Actes Sud. 
Portera, A. \& Grant, C. A. (2011). Intercultural and multicultural education: enhancing global interconnectedness. New York, NY: Routledge, Serie: Routledge research in education 39.

Portera, A. (2008) . Intercultural education in Europe: epistemological and semantic aspects. Intercultural Education, 19, 6, 481-491.

http://dx.doi.org/10.1080/14675980802568277

Sen, A. (2007). Identity and violence: The illusion of destiny. London: Penguin Books.

Skutnabb-Kangas, T., Phillipson, R., Mohanty, A. K.\& Panda, M. (2009). Social Justice Through Multilingual Education. Bristol: Multilingual Matters.

Taguieff, P.-A. (2012). Le nouveau national-populisme. Paris: CNRS Éditions.

Timm, L. (2009). The case of Denmark: an example of bad practice in intercultural education. Intercultural Education, 20,4, 385-390. http://dx.doi.org/10.1080/14675980903352035

Todd, S. (2009). Toward an imperfect education: Facing humanity, rethinking cosmopolitanism. Boulder: Paradigm Publishers.

Walker, M. (2007). Selecting valued capabilities for gender equality in education. In M. Walker \& E. Unterhalter (Eds.), Amartya Sen's capability approach and social justice in education (pp. 177-195). New York, NY: Palgrave Macmillan.

http://dx.doi.org/10.1057/9780230604810

Ytrehus, L. A. (2001). Beskrivelser av de andre: Etikk og politikk i forskning på etniske minoriteter. In L. A. Ytrehus (Eds.), Forestillinger om "den andre": Images of otherness (pp. 218-243). Kristiansand: Høyskoleforlaget.

Øzerk, K. (1993). Temaer i minoritetsrettet pedagogikk. Haslum: Oris Forlag.

Øzerk, K. (2010, May 10). Ble Stortinget ført bak lyset? Utdanning. Retrieved from http://www.utdanningsnytt.no/4/Meny-A/Meninger/Innspill...

Aarnes, A. (1998). Underveis mot den annen. Oslo: Vidarforlagets Kulturbibliotek, Erasmus-serien.

Frédérique Brossard Børhaug, How to challenge a culturalization of human existence? Promoting interculturalism and ethical thinking in education 